\title{
Characteristics of Authigenic Minerals around the Sulfate-Methane Transition Zone in the Methane-Rich Sediments of the Northern South China Sea: Inorganic Geochemical Evidence
}

\author{
Daidai Wu ${ }^{1,2,3}$, Tiantian Sun ${ }^{1,4}$, , Rui Xie ${ }^{1,2}$, Mengdi Pan ${ }^{1}$, Xuegang Chen ${ }^{4}$, Ying Ye ${ }^{4}$, \\ Lihua Liu ${ }^{1}$ and Nengyou $\mathrm{Wu}^{3,5}$ \\ 1 Key Laboratory of Gas Hydrate, Guangzhou Institute of Energy Conversion, Chinese Academy of sciences, \\ Guangzhou 510640, China \\ 2 Institution of South China Sea Ecology and Environmental Engineering, Chinese Academy of Science, \\ Guangzhou 510301, China \\ 3 Laboratory of Marine Mineral Resources, Pilot National Laboratory for Marine Sciences and \\ Technology (Qingdao), Qingdao 266071, China \\ 4 Ocean College, Zhejiang University, Zhoushan 316021, China \\ 5 Key Laboratory of Gas Hydrate, Ministry of Naturaland Resources, Qingdao Institute of Marine Geology, \\ Qingdao 266071, China \\ * Correspondence: 21534036@zju.edu.cn
}

Received: 23 May 2019; Accepted: 26 June 2019; Published: 28 June 2019

\begin{abstract}
Sediments at marine cold seep areas provide potential archives of past fluid flow, which allow insights into the evolution of past methane seepage activities. However, signals for anaerobic oxidation of methane (AOM) might be obscured in bulk sediments in cold-seep settings due to several factors, especially flood and turbidite deposition. Comprehensive inorganic data were gathered in this study to explore the availability of related records at cold seeps and to provide insights into the evolution of past methane seepage activities. Sediments collected from the site 973-4 in the Taixinan Basin on the northern slope of the South China Sea were characterized in terms of total carbon and sulfur, $\delta^{13} \mathrm{C}$ values of total organic carbon $\left(\delta^{13} \mathrm{C}_{\mathrm{TIC}}\right), \delta^{34} \mathrm{~S}$ values of chromium reducible sulfur $\left(\delta^{34} \mathrm{~S}_{\mathrm{CRS}}\right)$, and foraminiferal oxygen and carbon isotopes. The results confirmed a strong correlation between formation of authigenic minerals and AOM. Moreover, the ${ }^{34} \mathrm{~S}$ enrichments and abundant chromium reducible sulfur (CRS) contents in the authigenic sulfides in the sulfate-methane transition zone (SMTZ) within 619-900 cm below seafloor (cmbsf) reflected past high methane fluxes supported by constant methane seepages. Lithological distribution and AMS (Accelerator Mass Spectra) ${ }^{14} \mathrm{C}$ dating of planktonic foraminifera show that the turbidite $(\sim 35.14 \mathrm{ka})$ was related to a foraminifera-rich interval (Unit II: 440-619 cmbsf) and increased carbonate productivity during the last glacial maximum (LGM). Enrichment of Mo and $\mathrm{U}$ was observed accompanied by low contents of nutrient metals ( $\mathrm{Al}, \mathrm{Ti}, \mathrm{V}, \mathrm{Ni}, \mathrm{Fe}, \mathrm{Mn}$, and $\mathrm{Cu}$ ) in Unit II. The foraminifera-rich interval (Unit II) of cold seep sediments was probably linked to the phenomenon of inconsecutive sedimentary sequence due to the turbidites, which resulted in the lack of $\mathrm{Fe}, \mathrm{Mn}$, and Ba enrichment. There is no $\mathrm{U}$ enrichment but only Mo enrichment within Unit III, which might be related to $\mathrm{H}_{2} \mathrm{~S}$ produced by AOM during the methane seepages. Based on the above results, it can be speculated that this area has experienced multiple-episodes of methane seep events. Further exploration of AOM should focus on the risks of rapid deposition, especially the impact of turbidity current on sediments.
\end{abstract}

Keywords: authigenic minerals; anaerobic oxidation of methane; chromium reducible sulfur; methane seepage; South China Sea 


\section{Introduction}

"Gas hydrate" (natural gas hydrate) is an ice-like crystalline compound composed of gas and water molecules which forms at low-temperature and high-pressure environments [1]. As their formation is dominated by methane gas in nature, gas hydrates are also known as methane hydrates. Gas hydrate occurs naturally in the sediments beneath the permafrost and the continental slope in water depths more than $300 \mathrm{~m}$. Marine gas hydrate systems are important to economic society and the natural environment due to their viable energy potential as well as the geo-hazards they pose through large scale slope destabilization. Destabilization of gas hydrates will release methane, a potential greenhouse gas, which can affect the global climate [2-4]. Gas hydrate and its associated sediments have also become a focus of biogeochemical studies on the deep biosphere [5].

Marine sedimentary environment can be divided into several zones on the vertical cross-section according to the differences in concentrations of substances in marine sediments and the redox process in pore water. In fact, different geochemical zones usually overlap in spatial locations, and multiple oxidants and reaction products migrate, which also leads to dynamic changes in geochemical zones [6]. In addition, due to the content of oxidants such as $\mathrm{NO}_{3}{ }^{-}, \mathrm{Mn}_{\mathrm{IV}}, \mathrm{Fe}_{\mathrm{III}}$, and $\mathrm{SO}_{4}{ }^{2-}$ in pore water of marine sediments, the corresponding geochemical zone has different widths (centimeter or meter scale) [7]. In modern continental margins, sedimentary organic matter can be oxidized with dissolved oxygen and other oxidants. However, in areas with diffusive seepage, methane is mostly oxidized in the sediments at the expense of sulfate or metal oxidizers such as iron and manganese, by a series of biogeochemical processes $[8,9]$. In conclusion, when there is high methane flux in the sedimentary environment, the main biogeochemical reactions of concern are related to anaerobic oxidation of methane.

In cold seepage systems, large volumes of methane-rich fluids are transferred into seawater, where a series of important biogeochemical processes occur and sustain a broad diversity of ecosystems on the seafloor, relying on the energy provided by chemosynthetic microbes exploiting the oxidation of reduced chemical compounds $[10,11]$. The key biogeochemical process at seeps is the anaerobic oxidation of methane (AOM) coupled with sulfate reduction (SR) (1) [12].

$$
\mathrm{CH}_{4}+\mathrm{SO}_{4}^{2-} \rightarrow \mathrm{H}_{2} \mathrm{O}+\mathrm{HCO}_{3}^{-}+\mathrm{HS}^{-}
$$

This process produces dissolved inorganic carbon (DIC) and increases pore water alkalinity, thus favoring the precipitation of authigenic carbonates (2) [13].

$$
\mathrm{Ca}^{2+}+\mathrm{HCO}_{3}^{-} \rightarrow \mathrm{CaCO}_{3}+\mathrm{H}^{+}
$$

The produced DIC during AOM is characterized by highly depleted ${ }^{13} \mathrm{C}$ that is derived from methane [14,15]. At the same time, there is maximum accumulation of dissolved hydrogen sulfide in the sulfate-methane transition zone (SMTZ), where pore water sulfate and methane are depleted to near-zero concentrations [16,17]. The localized production of hydrogen sulfide commonly results in the precipitation of iron sulfide minerals (3) and (4) [18,19].

$$
\begin{gathered}
\mathrm{Fe}^{2+}+\mathrm{HS}^{-} \rightarrow \mathrm{FeS}+\mathrm{H}^{+} \\
\mathrm{FeS}+\mathrm{S}^{0} \rightarrow \mathrm{FeS}_{2}
\end{gathered}
$$

Many studies have revealed the presence of ${ }^{34} \mathrm{~S}$ enriched authigenic sulfides in seepage areas. Moreover, such positive $\delta^{34} S$ values were considered indicative of enhanced AOM-SR occurring at the SMTZ [20]. The carbon composition of upward migrating methane is mixed with other DIC sources, and the microbial preferences for ${ }^{32} \mathrm{SO}_{4}{ }^{2-}$ often result in ${ }^{34} \mathrm{~S}$-depleted sulfur in the pyrite [21]. Numerous studies have attempted to use geochemical proxies such as the content and isotopic anomalies of authigenic carbonates and pyrites to constrain methane seepage intensities and their variations [20,22-24]. 
Under different redox conditions, modern and ancient marine sediments are typically characterized by relative enrichment or depletion of various trace metals, such as the redox-sensitive metals Mo, $\mathrm{U}$, and $\mathrm{V}$ and trace metals such as $\mathrm{Cu}, \mathrm{Fe}$, and $\mathrm{Mn}$. Thus, they can be used as indicators of paleoredox conditions and paleoproductivity $[25,26]$. Although significant correlations exist between the concentrations of trace metals and sediment redox environments, it is unclear whether the relationship is predictable, particularly under non-steady state environments.

Here, a comprehensive inorganic geochemical data set is presented from the natural marine setting of Taixinan Basin using sediments collected during the cruise "Haiyang-6" in 2011. The non-steady state sedimentary environment along the continental margin of the northern slope of South China Sea is characterized by mass movements and attendant turbidity currents. Numerous periods of sea-level fall and lowstands have been reported $[27,28]$. The dynamics of fluid flows at seeps are characterized by changes in flow intensity and episodic seepages, which might be controlled by factors such as sea level variations, bottom water temperature fluctuations and the exhaustion of hydrocarbon sources that drive the dissociation of gas hydrates $[29,30]$. These particular depositional conditions have a significant impact on the biogeochemical processes of deeper marine sediments. In this study, we used only inorganic geochemistry to demonstrate past variations in methane fluxes. The findings of this study, would have significant implications for tracing past methane seepages, their intensities, and even possible occurrences of gas hydrate dissociation.

\section{Materials and Methods}

\subsection{Geological Setting}

The northern continental slope of the South China Sea extends from the southwestern end of Taiwan to the western end of the Xisha Trough in NE direction, with a total length of about $1350 \mathrm{~km}$ and a width of 143-342 km. The boundary between the northern continental slope and the deep-sea basin is 3400-3700 m, which is wide in the west and narrow in the east. The Pearl River and Hanjiang River in South China, Zeng Wenxi, and Gaoping River in Southwestern Taiwan all contribute significantly to the sediments in this area [31]. At the same time, because the South China Sea is located at 22 degrees north latitude, it is between the equator and the Tropic of Cancer. Thus, the monsoon climate is affected by the southwest monsoon in summer and northeast monsoon in winter. The driving force of the surface current in the South China Sea is influenced by the monsoon. In summer and winter, the Luzon Strait on the southern side of Taiwan Island ensures that there will be a sustained Kuroshio branch current entering and flowing to the southwest. Therefore, the Kuroshio also has a great impact on the sedimentation of the northern continental slope of the South China Sea [32]. In addition, there are some small asymmetric folds in the southeastern margin of the northern continental slope of the South China Sea. The development of these folds also has a significant influence on the sedimentary process of the northern continental slope of the South China Sea [33].

The northern continental slope area of the South China Sea is the junction of different tectonic units. Thus, it has the characteristics of huge topographic slopes and relatively developed faults in underlying strata. Many faults cut through newer sedimentary layers and extend to the vicinity of seabed sediments, opening up favorable channels for gas migration from the lower part to shallow formation, while fold structures can capture natural gas more easily, thus forming methane seepage development areas [34,35]. In May 2007 and June-September 2013, a variety of hydrate samples were drilled in Shenhu area of Baiyun Depression on the northern slope of the South China Sea and near the central uplift of the Southwestern Taiwanese Basin [36,37]. The drilling of these hydrate samples indicated that the northern part of the South China Sea was indeed a gas hydrate occurrence area. Moreover, the discovery of a large number of methanogenic carbonate nodules showed that methane escaped from the area [38]. The Taixinan Basin, also known as the Tainan Basin, is located to the east of Dongsha Islands in the Northeastern South China Sea. It is about 400 kilometers long and 150 kilometers wide with an area of more than 60,000 square kilometers. The complex submarine 
topography, widespread existence of folds, mud diapers and landslides, as well as fault-fold systems, all create a favorable tectonic environment for the development and migration of hydrocarbons and hydrates [39,40]. The Taixinan Basin contains thick layers of Late Cenozoic sediments through submarine canyons, up to $10 \mathrm{~km}$ thick, which accumulate in the form of turbid fluids, natural levees and sand-rich sediments such as submarine fans [41].

\subsection{Materials and Methods}

A $13.75 \mathrm{~m}$ long sediment column from site 973-4 was retrieved by the "Haiyang-6" cruise ship in 2011 from a water depth of 1666 m near the Jiulong Methane Reef in the Taixinan Basin, Northern South China Sea (SCS) $\left(118^{\circ} 49.0818^{\prime} \mathrm{E}, 21^{\circ} 54.3247^{\prime} \mathrm{N}\right)$ (Figure 1). The piston core was then divided into 63 samples, every $20 \mathrm{~cm}$ below seafloor (cmbsf). A sample was selected every $20 \mathrm{cmbsf}$ in the 0-1375 cmbsf interval, and a total of 63 samples were used for foraminifera community studies, with no samples at 558-560 cmbsf, 1038-1040 cmbsf, 1158-1196 cmbsf and 1239-1241 cmbsf. Each sample was freeze-dried, and some samples were powdered manually in an agate mortar for subsequent geochemical analysis.

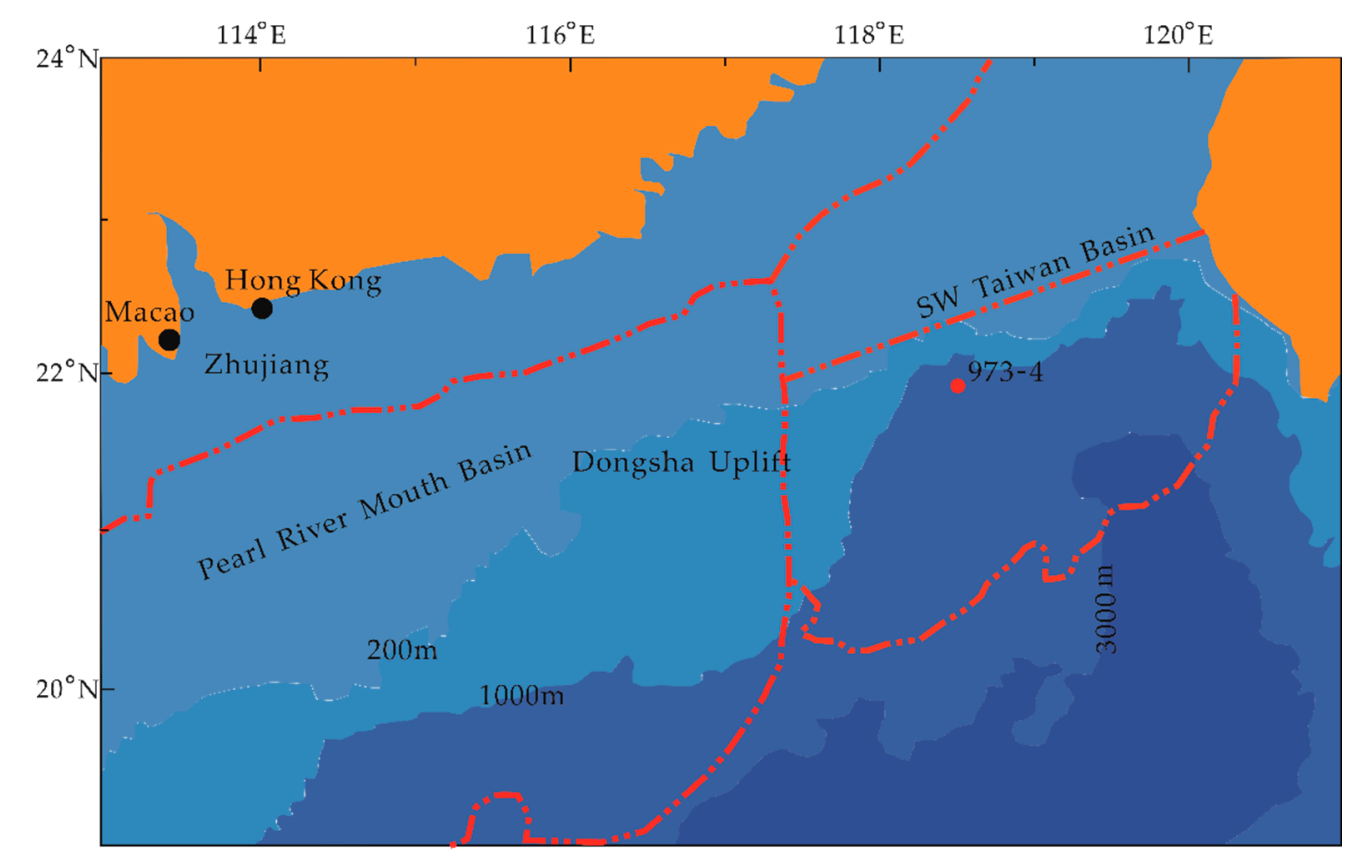

Figure 1. Map showing the locations of the study site 973-4 on the northern slope South China Sea (Modified from Pan et al. [42]).

Chromium reducible sulfur (mainly FeS, FeS2) found in samples was extracted using a modified method of [43]. This reduction method can release sulfur in all sulfide lattices, and the obtained sulfur content was almost the total content of chromium reducible sulfur (CRS) [6,43]. The reduced sulfur was converted to $\mathrm{H}_{2} \mathrm{~S}$ gas, which was blown out by the carrier gas (nitrogen), and then, precipitated by passing through $\mathrm{AgNO}_{3}-\mathrm{NH}_{3} \mathrm{H}_{2} \mathrm{O}$ solution to obtain silver sulfide. The silver sulfide was filtered, dried and weighed. Then, the weight percentage of chromium reducible sulfide (CRS) in the deposit was calculated according to the weight of precipitated silver sulfide. Detailed experimental steps can be found in the report by Pan [42].

During the experiment, the quantitative addition of pyrite as a standard sample resulted in the recovery rate of $88-92 \%$. The silver sulfide was then sent to the State Key Laboratory of Biogeology and Environmental Geology of China University of Geosciences (Wuhan, China) for the analysis of $\delta^{34} \mathrm{~S}$ using an elemental analysis-isotope ratio mass spectrometer (DELTA V PLUS, Semerfly Technology (China) Co.; Ltd, Shanghai, China). The standard deviation of the measurement was less than $0.2 \%$ o 
Vienna-defined Canyon Diablo Troilite (VCDT). All results are reported here in standard delta notation as per mil deviations from the Vienna-defined Canyon Diablo Troilite (VCDT). Measurement errors of $\sim 0.2 \%$ o $(1 \sigma)$ were calculated from replicate analyses of the IAEA international standards: IAEA S1 $(-0.3 \%$ o), IAEA S2 $(+22.7 \%$ o), and IAEA S3 $(-32.3 \%$ o).

All sixty-three freeze-dried sediment samples were ground into uniform powder in agate mortar. Total organic carbon (TOC) was measured by ElementarTM Vario with an accuracy of $1 \%(5 \mathrm{mg} / \mathrm{L})$. The powdered samples were determined by ElementarTM Vario EL cube elemental analyzer (Elementar Analysensysteme $\mathrm{GmbH}$, Langenselbold, Germany). The average values of each sample were obtained twice. The analytical accuracy of total carbon (TC) and total sulfur (TS) was $0.1 \%$. The total inorganic carbon (TIC) was mainly calcium carbonate. The calculation method of mass fraction was $\mathrm{C}(\mathrm{CaCO})=\left(\mathrm{C}_{\mathrm{TC}}-\mathrm{C}_{\mathrm{TOC}}\right) * 8.33[44]$.

The mass fraction of foraminifera in sediments was calculated as follows: The mass fraction of foraminifera in sediments was estimated based on the average mass of foraminifera. Three samples of foraminifera from site 973-4 with different depths were selected: 973-4-83 sample from the upper part of the site, 973-4-223 sample from the middle part and 973-4-383 sample from the lower part. One hundred foraminifera of different sizes and species were selected from these different samples and weighed accurately. The average mass of foraminifera was calculated, and then the mass fraction distribution of foraminifera with depth was calculated using the content data of foraminifera.

The elemental analysis of all 63 freeze-dried sediment samples was performed using X-ray fluorescence (XRF) on a Thermo ARL ADVANTta IntelliPowerTM 2000 spectrometer (Thermo Fisher Scientific, Waltham, USA), which was available at the Zhejiang University of Technology, China. The relative standard deviation of the measurement was less than $5 \%$. A total of 63 sediment samples were analyzed for trace elements by Agilent 7700e ICP-MS (Sample Solution Technology Co., Ltd., Wuhan, China) in the Analytical and Testing Center of Wuhan Shangpu Analysis Technology Co., Ltd. The treatment of sediment samples and the specific testing methods for major and trace elements have been described elsewhere [42]. To compare the respective authigenic enrichments of the trace metals in the sediment, enrichment factors $(\mathrm{EF})$ were used, which are defined as $\mathrm{XEF}=[(\mathrm{X} / \mathrm{Al})$ sample/(X/Al) PAAS], where $X$ and $\mathrm{Al}$ represent the weight concentrations of elements $\mathrm{X}$ and $\mathrm{Al}$, respectively. The samples were normalized using the Post Archean Australian Shale (PAAS) compositions [45]. In general, XEF N 3 represent a detectable authigenic enrichment, and XEF N 10 represent a moderate to strong enrichment [25].

\section{Results}

\subsection{Core Description and Radiocarbon Dating}

The core section was composed of four lithological parts (Figure 2). Unit I at the depth of 0-440 centimeters below sea floor (cmbsf) mainly contained celadon silty clay. Unit II at $440-619 \mathrm{cmbsf}$ mainly consisted of gray clayey silt. In particular, massive foraminiferal sand was found in 479-494 cmbsf, and black iron sulfide stains were found in $494-510 \mathrm{cmbsf}$ sediments. The middle part (530-603 cmbsf) was composed of gray-green clayey silt with visible foraminiferal shells. The low part at 619-900 cmbsf (Unit III) and 900-1365 cmbsf (Unit IV) were mainly composed of dense gray silty clay with different degrees of black hydrogen sulfide. It was noteworthy that the color and grain size of sediments at $603 \mathrm{cmbsf}$ were clearly defined. Below $619 \mathrm{cmbsf}$, the core section emitted pungent gases such as hydrogen sulfide [46]. 


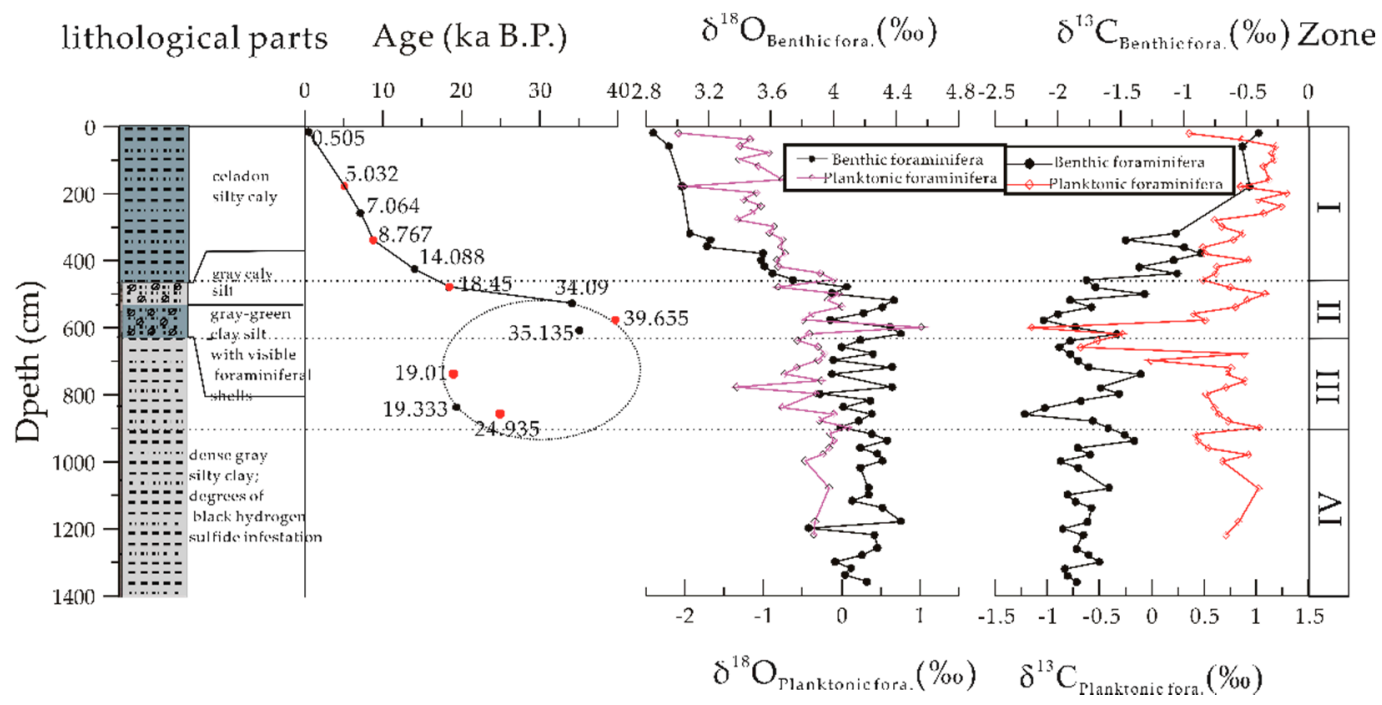

Figure 2. The lithological distribution [46] and AMS ${ }^{14} \mathrm{C}$ age datum from site 973-4. Red dots represent the data of [42], while black dots represent the data of Lin [47]. Profiles of carbon and oxygen isotopic composition of benthic foraminifera (e.g., Uvigerina spp.) and planktonic foraminifera (P. obliquiloculata) at site 973-4 [48].

The AMS ${ }^{14} \mathrm{C}$ dating results (Figure 2) of planktonic foraminifera at site 973-4 were collected according to Lin [47] and Pan [42]. The planktonic foraminifera (N. dutertrei) collected from 12 samples throughout the site yielded an inconsecutive sedimentary sequence, especially in Unit II. Unit I of celadon silty clay $(0-440 \mathrm{cmbsf})$ increased in age with depth from $0.5-18.45 \mathrm{ka}$ B.P, while the foraminifera-rich Unit II (440-619 cmbsf) was deposited between 34.09-39.65 ka B.P. Below the $619 \mathrm{cmbsf}$ part, the core section recorded ages of around 19.00-25.94 ka B.P. The inconsecutive sedimentary sequence (Unit II) at this site may be related to turbidity current and other sedimentary events or the activities of underlying gas hydrate reservoirs.

\subsection{Relevant Data of Carbonates in Bulk Sediments}

The contents of $\mathrm{CaO}$, TC and TIC from site 973-4 (Figure 3) exhibited similar geochemical behavior and were relatively stable throughout the core. Their values fluctuated at around $4 \mathrm{wt} . \%, 1.45 \mathrm{wt} \%$, and $1.12 \mathrm{wt} . \%$, except for obvious variations in Unit II, with the maximum values reaching $23.3 \mathrm{wt} . \%$, $5.63 \mathrm{wt} \%$, and $5.43 \mathrm{wt} \%$, respectively. Total organic carbon (TOC) content ranged from $0.18 \mathrm{wt} . \%$ to $1.3 \mathrm{wt} . \%$ with a few appreciable changes throughout the core.

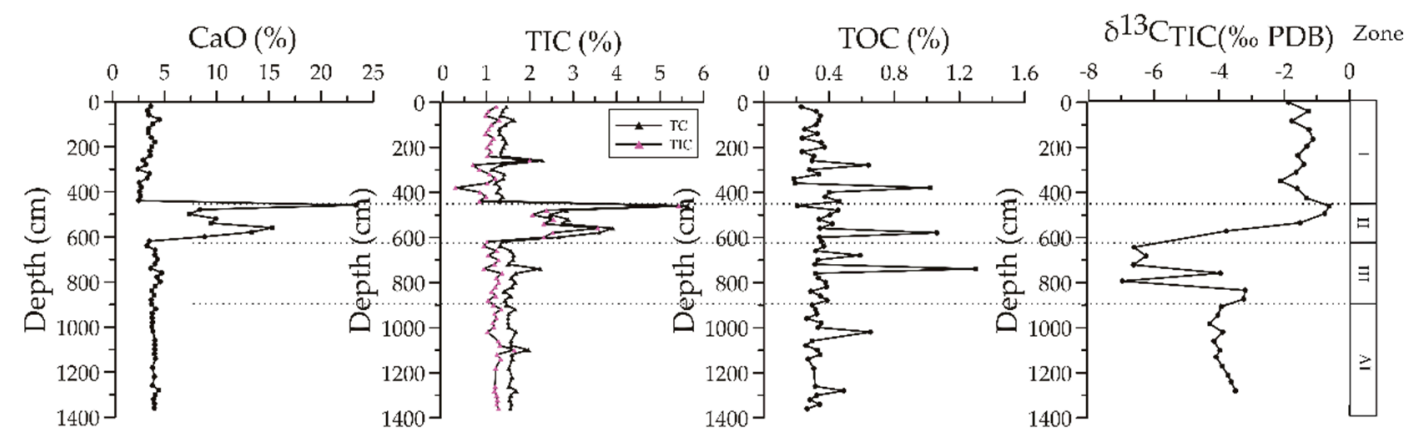

Figure 3. Depth profiles of Cao, total inorganic carbon (TIC), and total organic carbon (TOC) as well as carbon isotopic composition of total inorganic carbon. Carbon isotopic composition of TIC are adopted from Zhang et al. [49]. 


\subsection{Chromium Reducible Sulfur and $\delta^{34} S_{C R S}$}

The chromium reducible sulfur (CRS) content at different depths measured at site 973-4 showed significant differences (Figure 4) (Appendix A Table A1). The content of CRS in Unit I was relatively low, ranging from 0.072 to 0.139 wt. $\%$, with an average value of 0.113 wt. $\%$. The CRS content exhibited an almost linearly increasing trend with depth in Unit II, ranging from $0.123-1.385$ wt.\%, with an average of $0.376 \mathrm{wt}$ \%. In Unit III, CRS content remained at a relatively high level with a maximum value of $1.211 \mathrm{wt} \%$. However, in Unit IV, CRS content began to decline and remained relatively stable, ranging from $0.023-0.183 \mathrm{wt} \%$. The profile of $\delta^{34} S_{C R S}$ was similar to that of CRS content. The $\delta^{34} S_{C R S}$ values ranged from $-41.14 \%$ o $\sim 23.56 \%$. Above $619 \mathrm{cmbsf}, \delta^{34} \mathrm{~S}_{\mathrm{CRS}}$ values decreased from enriched to depleted isotopic ratios.

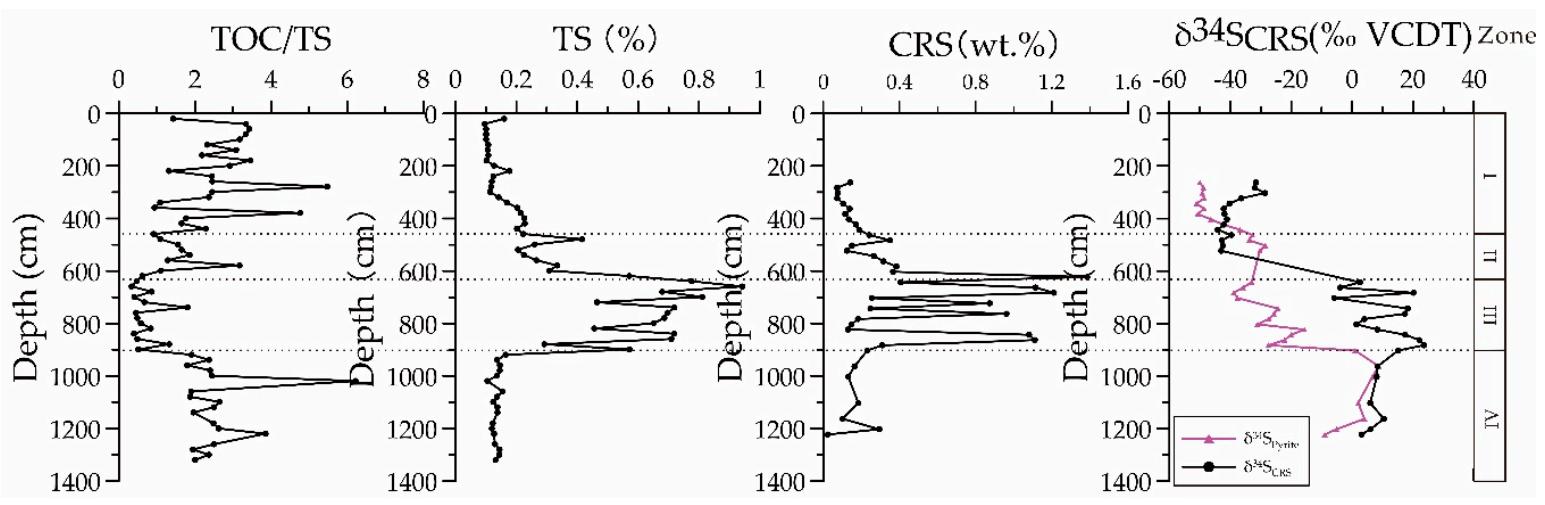

Figure 4. The contents of total sulfur (TS) and chromium reducible sulfur (CRS), and TOC/TS ratios, and sulfur isotopes of CRS $\left(\delta^{34} S_{C R S}\right)$ with depth in sediments of site $973-4 . \delta^{34} S_{\text {Pyrite }}$ values of bulk sediments in site 973-4 were taken from Lin et al. [47].

\subsection{Concentration Profiles of Major and Trace Elements}

The contents of selected major and trace elements in sediments of site 973-4 are presented in Figure 5.

The contents of $\mathrm{Al}, \mathrm{Ti}, \mathrm{Fe}, \mathrm{Mn}$, and $\mathrm{Ba}$ in Unit II were lower compared to the other parts, and their average contents were $9.58 \%, 27.11 \%, 3.75 \%, 0.057 \%$, and $433.33 \mathrm{ppm}$, respectively. The Mo and U contents showed obvious differences. The Mo contents ranged from 0.44 to $1.12 \mathrm{ppm}$ with depth of the core, while the U contents ranged from 2.62 to $4.18 \mathrm{ppm}$. However, only Unit II exhibited moderate enrichment of Mo and U. The ratios of V/Sc showed no anomalies in the core except for Unit III, where the contents were slightly lower. 

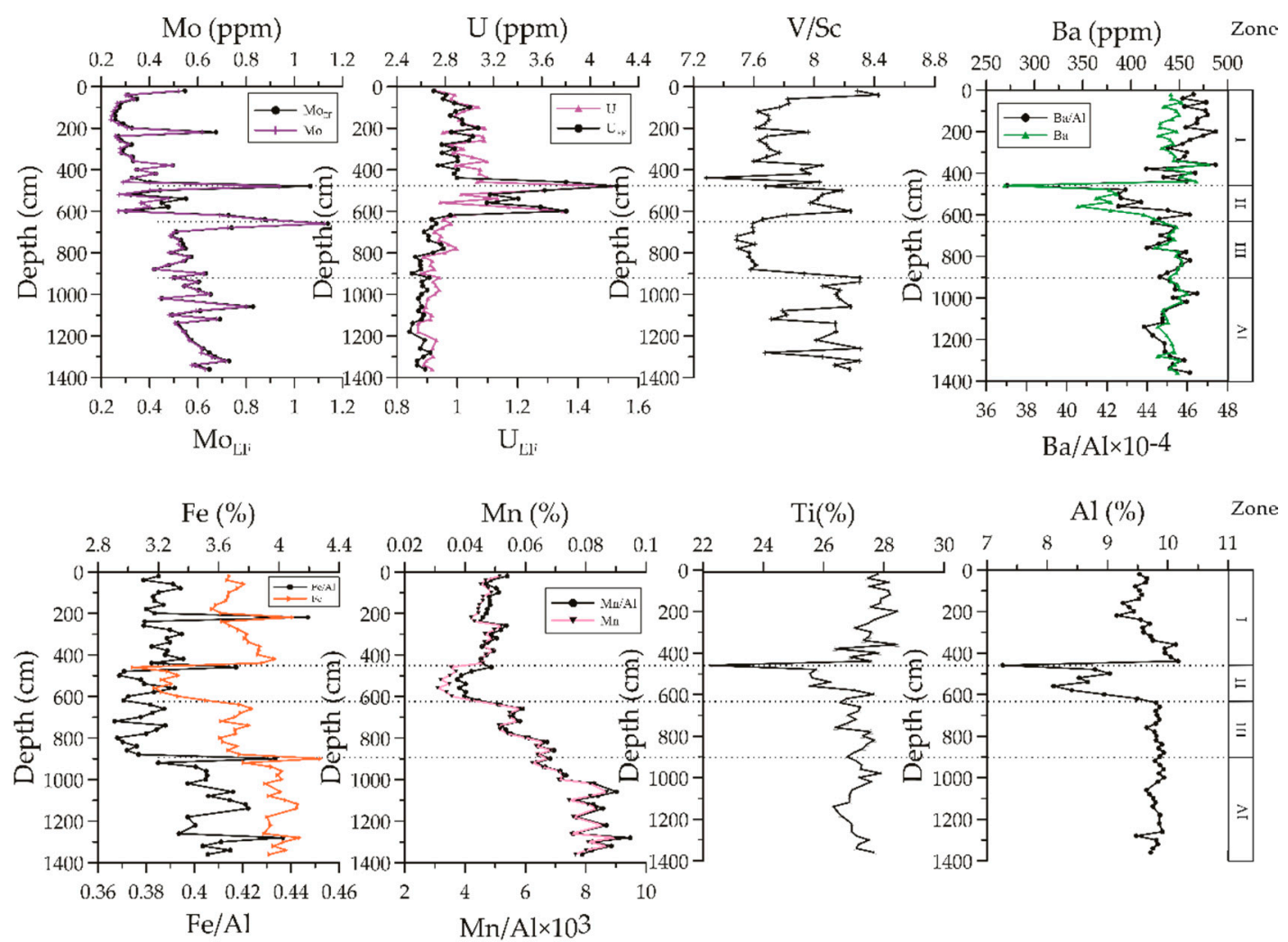

Figure 5. Depth profiles of $\mathrm{Fe}, \mathrm{Mn}, \mathrm{Ti}, \mathrm{Al}, \mathrm{Mo}, \mathrm{U}, \mathrm{Ba}$, and ratios of $\mathrm{Fe} / \mathrm{Al}, \mathrm{Mn} / \mathrm{Al}, \mathrm{Mo}_{\mathrm{EF}}, \mathrm{U}_{\mathrm{EF}}, \mathrm{Mn} / \mathrm{Al}$, $\mathrm{V} / \mathrm{Sc}$, and $\mathrm{Ba} / \mathrm{Al}$ in sediments of site $973-4$.

\section{Discussion}

\subsection{Evidence of Anaerobic Oxidation of Methane in Sediments}

The fluxes and rates of methane fluids released by the decomposition of deep gas hydrates vary in different areas of the sea and different geological periods. Based on this, the migration modes of methane fluids can be roughly divided into two types: diffusion type and seepage type. The former is usually in the form of slow release, where the methane fluid diffuses upward or around the sediment pores. The latter is in the form of intense seepage, where a large amount of methane fluid seeps upward along the sediment pores or structural fissures. The types and contents of authigenic minerals formed by different migration types of methane fluids are also different. The sulfate-methane transition zone (SMTZ) is usually located in the shallow surface sediments or even in the water body in sedimentary environments having intense seepage of methane. The strong anaerobic oxidation of methane (AOM; reaction (1)) produces $\mathrm{HCO}_{3}{ }^{-}$, which promotes the formation of authigenic carbonates with extremely negative ${ }^{13} \mathrm{C}$ values (generally less than $-25 \%$ VCDT) [50,51]. AOM-SR occurring in the SMTZ mainly results in the formation of authigenic iron sulfide minerals in the sedimentary environment where methane seeps slowly. However, AOM might limit the precipitation of authigenic carbonates whereas it is beneficial for the final conversion of intermediate products such as $\mathrm{S}^{0}, \mathrm{SO}_{3}{ }^{2-}$, and $\mathrm{S}_{2} \mathrm{O}_{3}{ }^{2-}$ into pyrite [52]. The resultant authigenic minerals are potential archives of past fluid flow, especially in combination with dating results. Thus, they can provide insights into the evolution of past methane seepages activities $[11,29,30]$.

\subsubsection{CRS and $\delta^{34} \mathrm{~S}_{\mathrm{CRS}}$}

The burial of authigenic sulfide in anoxic sediments is primarily controlled by the activity of sulfate reducing bacteria [53]. It should be noted that the typical burial ratio (weight) of organic carbon to sulfur for normal marine sediments falls within a relatively narrow range (2.0-3.6) [54]. By correlation 
analysis of TOC and TS contents in site 973-4, it can be seen that the characteristics of different sections were obviously different (Figure 4). In Unit I and Unit II, the CRS contents were generally at a low level (average value of $0.245 \mathrm{wt} . \%)$. The $\delta^{34} \mathrm{~S}_{\mathrm{CRS}}$ values $(-40.26 \sim-14.68 \%$ oVCDT) were strongly depleted, which can also be seen in other continental margin sediments (Figure 4), which may be a result of the disproportionation of microbial sulfur occurring close to the sediment-water interface [20], additional sulfur cycling through the sulfate reduction zone [55], and/or slow sulfate reaction rates [56]. The similar trend of $\delta^{34} S_{\text {CRS }}$ values and $\delta^{34} S_{\text {Pyrite }}$ values (Figure 4 ) suggest that iron-sulfide minerals represent the most important form of sulfur in sediment and that the TS content can be used to represent the trend of pyritization in sediment in site 973-4. A positive relationship between TOC and TS was observed. The average TOC/TS value was 2.634 , close to 2.8 , which belongs to normal marine sedimentary environment. This indicates that the CRS content in the sediments of Unit I and Unit II were mainly controlled by active organic matter through organoclastic sulfate reduction. However, the TOC/TS ratios of sediments within Unit II and below $619 \mathrm{cmbsf}$ range did not follow this trend. They were lower than the typical average ratio (2-3.6), and in particular, the average TOC/TS ratio was only 0.71 in Unit IV. On the other hand, the contents of CRS and $\delta^{34} S_{C R S}$ increased dramatically within Unit III while they remained at a relatively high level below Unit III. This indicates that the consumption of sulfate is increasing, or even relatively insufficient, which leads to excessive consumption of ${ }^{34} \mathrm{~S}$ in sulfate, resulting in a rapid increase of ${ }^{34} \mathrm{~S}$ in sulfides, usually close to the value of sulfate in seawater. This was a pattern similar to those found in the Nankai Trough and northern SCS, where the occurrence of AOM significantly increase CRS contents and $\delta^{34} S_{C R S}$ values of the sediments $[6,57]$. Therefore, the observed high CRS content and $\delta^{34} S_{C R S}$ values within depths of Unit III may indicate the intensification of AOM-SR and the current and/or past locations of the SMTZ. It has been well documented that the occurrence of the AOM at the SMTZ within Unit III could produce additional $\mathrm{H}_{2} \mathrm{~S}$, which diffused upward and thus decreased the TOC/TS ratio of sediments within Unit II [23]. A low CRS content was observed only at Unit IV, which is coincidence with the average low TOC/TS ratio in this Unit. However, Liu et al [49] demonstrated that the main biogeochemical processes in Unit IV is controlled by iron mediated anaerobic oxidation of methane (Fe-AOM), which further confirms that of methane rich fluids are well developed in this site.

\subsubsection{Authigenic Carbonates Precipitation}

Numerous surveys and researches have indicated that authigenic carbonates originating from cold seeps are highly depleted in ${ }^{13} \mathrm{C}$, which serves as an important indicator of past methane seepage and the source of seep fluids $[25,30,53,58]$. Based on TC, TIC, $\mathrm{CaO}$ contents and $\delta^{13} \mathrm{C}_{\text {TIC }}$ values (Figure 3) in the four intervals (0-440, 440-619, 619-900, and 900-1360 cmbsf), the sediment core at site 973-4 reflects background sedimentation, and different prominent biogeochemical processes in different intervals. In fact, Unit III sediments revealed highly ${ }^{13} \mathrm{C}$-depleted (extremely negative values) authigenic carbonates, which indicated AOM-SR. On the other hand Unit IV had relatively ${ }^{13} \mathrm{C}$-depleted $(-4.3 \%$ o) authigenic carbonates and was sulfate-poor due to iron-AOM, as demonstrated by Liu [49]. Nevertheless, the sulfate concentrations and $\delta^{13} C_{\text {TIC }}$ values may allow recognition of organoclastic sulfate reduction (OSR) in Unit I where the minimum $\delta^{13} \mathrm{C}_{\mathrm{TIC}}$ value was $-2 \%$. The TC, $\mathrm{CaO}$, and TIC profiles exhibited similar tendencies in the sediments at site 973-4, except for Unit II, which had relatively high contents. This also means that the high carbon content in Unit II range was due to the abnormal increase in content of $\mathrm{CaCO}_{3}$. This abnormal increase in content of $\mathrm{CaCO}_{3}$ within Unit II needs to be further investigated.

Before analyzing the source of carbonate minerals in the site 973-4, the abnormal increase in carbonate content in the depth range of Unit II was analyzed (Figure 3). Some studies $[42,46,48]$ have shown that foraminiferal assemblages in this cold seep site display high species abundance and diversity. A total of 9111 benthic foraminifera were obtained from 63 identified samples [48]. In addition, the samples also contained a large number of planktonic foraminifera and a small number of Ostracoda individuals. In the shallow depth of Unit II, foraminifera biomass increased significantly. Within the 
range of 458-618 cmbsf sampling depth, foraminifera increased sharply and reached the maximum at a depth of $459 \mathrm{cmbsf}$. The average abundance of foraminifera in this horizon reached $47 \mathrm{pieces} / \mathrm{g}$, which was much higher than that of other Units. Therefore, it is speculated that the abnormal increase in $\mathrm{CaCO}_{3}$ in this area was not caused by the input of terrestrial materials, but probably by the increase in foraminiferal contents.

Benthic foraminifera inhabiting water-rock interfaces or sediments can effectively record changes in dissolved inorganic carbon in the surrounding environment [42,47,59]. According to the carbon and oxygen isotopes of benthic foraminifera (Figure 2) at site 973-4 reported by Zhang [48], the variation of $\mathrm{CaCO}_{3}$ contents with depth was compared. It was found that Unit II has recorded deposition since Marine Isotope Stage 2-3 (MIS2-3) period including the last glacial maximum (LGM). The carbon and oxygen isotope compositions of benthic foraminiferal shells decreased rapidly, similar to that of $\delta^{13} C_{\text {TIC }}$. It can be inferred that Unit II was the result of various sedimentary processes. In addition to early diagenesis, reductive fluids brought about by methane seepage in the bottom had a great influence on the contents of foraminiferal shells and authigenic minerals (authigenic carbonate, CRS) and their isotopic compositions.

\subsection{Source Origin of Methane-Rich Fluids: Constraint of the Stable C-O-S Isotope}

Excluding the impact of methane seepage in Unit II, the sediments displayed a sharp decrease in $\delta^{13} \mathrm{C}_{\mathrm{TIC}}$ from -0.6 to $-3.8 \%$ o, accompanied by a dramatic increase in $\delta^{34} \mathrm{~S}_{\mathrm{CRS}}$ from -44.3 to $2.55 \%$. The carbon and oxygen isotopes of benthic foraminifera (e.g., Uvigerina spp.) and planktonic foraminifera (P. obliquiloculata) at site 973-4 decreased gradually at Unit II. Moreover, the carbon isotope values were both negative, which was not observed in other parts (Figure 2). Pan [60] analyzed the characteristics of foraminifera community in sediments from site 973-4. The results showed that the performance and diversity of benthic foraminifera in Unit II reached the maximum, and the community composition was completely different from that in other parts. This high density and abundance of foraminifera and carbonates also indicated that the stratum might be disturbed by turbidity current. Considering the fact that the overall $\delta^{13} C_{\text {TIC }}$ value of sediments was much closer to biogenic end-member, it is suggested that the elemental $\mathrm{C}, \mathrm{O}$, and $\mathrm{S}$ in this interval likely originated from other sources than methane.

The lithological analysis of site 973-4 (Figure 2) shows that the sediments in Unit II were mainly clayey and silty, with large amounts of aggregated foraminiferal sand, shell debris, and carbonate blocks. Generally, the grain size of sediments increased compared with other intervals, which is the key characteristic of turbidity current. Several studies have found that the ${ }^{14} \mathrm{C}$ age of sediments deposited from the cold seepage system may represent the maximum age of carbonate growth $[59,60]$. Nevertheless, the ${ }^{14} \mathrm{C}$ dating in this study still provided a constraint for the carbonate growth. The planktonic foraminifera (N. dutertrei) throughout the site yielded an inconsecutive sedimentary sequence. It is therefore suggested that an abrupt increase in methane flux occurred between $14 \mathrm{ka}$ and $19 \mathrm{ka}$, bringing sediments with an older age of 34.09-39.65 ka. The sampling interval of Unit II might have been affected by turbidity current [46]. During this period, there was a dramatic drop in the sea level all over the world, and the sea level was $120 \mathrm{~m}$ lower in the LGM than that at present $[61,62]$. The ESC sea level even suffered a drop of up to 150-160 m [63], and most of the continental shelf areas were exposed to the atmosphere. Some large rivers, including the Yangtze, are reported to have emptied directly into the western slope of OT $[64,65]$. The turbidites mainly developed during periods of sea level fall and lowstand in the northern and southern SCS [66]. Changes in pressure and temperature as well as the activation of fluid channels [29] likely resulted in extensive instability and decomposition of natural gas hydrates in the main continental shelf. Numerous studies have demonstrated that vigorous hydrocarbon fluid seepages occurred all over the continental shelf globally during this period, including the Black Sea [67], the Eastern Margin of Japan Sea [59], the Gulf of Mexico [29] and the South China Sea $[68,69]$. Due to the limitations of the AMS ${ }^{14} \mathrm{C}$ dating method, it can be tentatively speculated that the gas hydrate dissociation in the study area was related to this global sea level falling event. Moreover, compared to the Holocene, the productivity of surface waters on the northern continental 
slope of the SCS was significantly higher during the last glacial maximum [70]. Since the last glacial maximum, the bulk carbon and sulfur isotopic data suggest that the SMTZ was relatively stable at roughly the same depth with a continuous but decreased flux of methane. Foraminiferal abundances can increase due to a sudden input of high quality organic matter, or enhanced reproductive activity and/or rapid growth [71]. This late transport in dynamic environments and the mixing of pore fluids likely affected the $\mathrm{C}-\mathrm{O}-\mathrm{S}$ isotope composition of foraminiferal communities and various authigenic minerals. Similar trends were observed in deep-sea basins in the western SCS and Dongsha area on the northern slope of the SCS, which are considered to be the result of turbidity currents [72].

\subsection{Conditions for Mo Enrichments in the Methane Seep Environments}

In this study, redox-sensitive elements Mo and $U$ exhibited non-negligible anomalies in response to the intense methane seepages recognized in Unit II of the profiles (Figure 5), while the contents of these elements remained at a high level without abnormal changes in Unit IV. Alternatively, $U_{\mathrm{EF}}$ and $\mathrm{V} / \mathrm{Sc}$ exhibited a range of responses to the intense methane seepages and showed detectable to moderate enrichments in the seep-impacted sediments in Unit II. U was strongly enriched in the seep-impacted sediments within Unit II. There were two Mo enrichments in Unite II and III. The upper one is at $479 \mathrm{cmbsf}$ within Unit II where the Mo content of $0.94 \mathrm{ppm}$ was observed, while the lower one is between 619 and $679 \mathrm{cmbsf}$ within Unit III.

Previous studies suggest that the two key factors that may control redox-sensitive enrichments are the abundance of a metal in the terrigenous background sediment and the aqueous concentration of the metal in the overlying seawater [25]. However, the contents of terrigenous metals, such as $\mathrm{Al}$ and $\mathrm{Ti}$, also influence the trace metal enrichment factors [26]. Due to the low $\mathrm{Al}$ and Ti contents, the high enrichments for Mo and U in Unit II with foraminifera-rich interval cannot be ascribed to the low $\mathrm{Al}$ content of sediments. Compared to the other trace elements $\mathrm{Fe}, \mathrm{Mn}$, and $\mathrm{Ba}$ had the lowest contents in the terrigenous background, which showed mainly suboxic conditions. Therefore, the Mo and $\mathrm{U}$ contents in this interval were unlikely to be influenced by the terrigenous background, and were instead influenced by suboxic conditions.

In modern continental margins, Mo enrichments commonly develop in TOC-rich surface sediments [73]. Under such environments, other redox sensitive elements (e.g., $\mathrm{Ni}, \mathrm{Cu}$, and $\mathrm{Zn}$ ) that are closely associated with organic matter also show corresponding enrichments [73,74]. However, there is also a limited flux of trace elements to the sediment, or upward movement of the paleo-sulfate-methane transition zone (SMTZ). In this study, Mo and U enrichments occur in foraminifera-rich interval (Unit II) (Figure 6), and redox sensitive elements, such as $\mathrm{Fe}, \mathrm{Mn}, \mathrm{Ba}$, and $\mathrm{V}$ are not enriched (Appendix $\mathrm{A}$ Table A2). The foraminifera-rich interval (Unit II) of cold seep sediments was probably linked to the phenomenon of inconsecutive sedimentary sequence due to the turbidites, which resulted in the lack of $\mathrm{Fe}, \mathrm{Mn}$, and Ba enrichment. Anschutz et al. [75] reported that the redox conditions of sediments under turbidity current became anoxic only four months after turbidite deposition, which explained the development of reducing environment. Deep-sea turbidites, which typically non-steady state conditions and are widely found in the geologic record, are deemed to be an ideal "natural laboratory" to study the postdepositional mobility of redox-sensitive metals [3]. Therefore, the enrichment of $U$ and Mo in foraminifera-rich interval may be related to turbidite deposition, which slowed oxygen diffusion into the sediment, allowing anoxic environments to occur in the sediments.

However, it is worth noting that there is no U enrichment but only Mo enrichment within Unit III, which might be related to $\mathrm{H}_{2} \mathrm{~S}$ produced by AOM during the methane seepages. In fact, AOM coupled with sulfate reduction can produce abundant $\mathrm{H}_{2} \mathrm{~S}$ at cold seeps and generate sulfidic environments that favor Mo enrichments in sediments and result in high CRS content and $\delta^{34} S_{C R S}$ values within depths of Unit III, as also proposed by recent studies [22,76-78]. 
Low terrigenous input

(low sea level, flooded shelf)

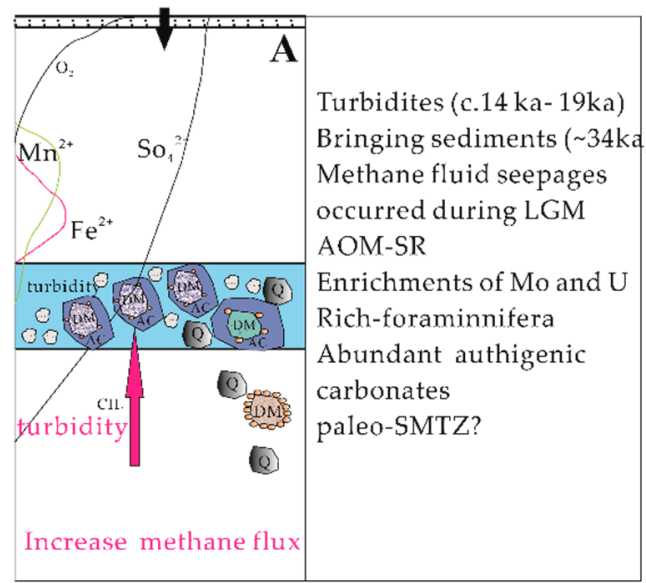

High terrigenous input

(low sea level, dry shelf)

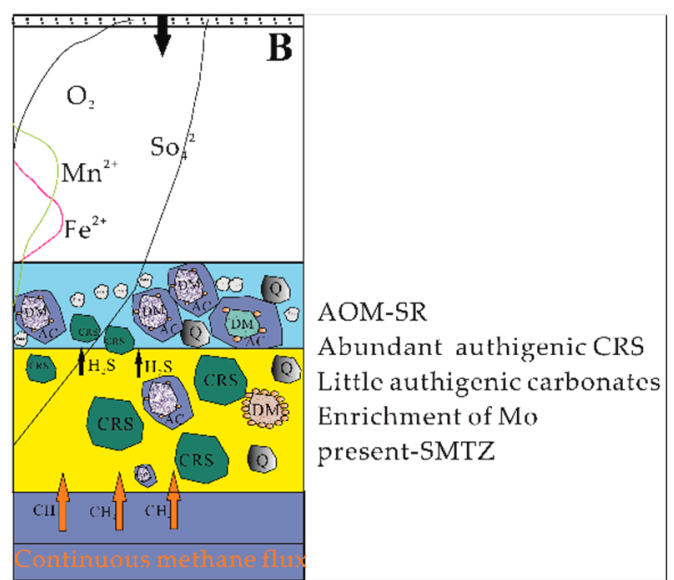

Figure 6. Schematic illustration of relevant depositional and diagenetic processes leading to methane seeping in continental slope setting affected by turbidity during (A) and after (B) the last glaciation. Q-quartz grain; DM-dark minerals; AC—authigenic minerals; CRS—chromium reduction sulfur; Fora.-foraminifera; AOM-SR: anaerobic oxidation of methane-sulfate reduction; SMTZ: sulfate methane transition zone; LGM: last glacial maximum.

\subsection{Implications for the Dynamics of Past Methane Seepages}

From the above analysis, it can be seen that site 973-4 recorded more methane seeps since $35 \mathrm{ka}$. Here, a conceptual model (Figure 6) is presented to simply describe the evolutionary stages of abundant authigenic minerals inducted by AOM. In the first stage $(\sim 35.14 \mathrm{ka})$, lithology, ${ }^{14} \mathrm{C}$ dating and carbon and oxygen isotopes of foraminifera in the sedimentary column indicated that Unit II may have developed turbidity currents. It is therefore suggested that an abrupt increase in methane flux occurred between $14 \mathrm{ka}$ and $19 \mathrm{ka}$, bringing sediments with an older age of 34.09-39.65 ka. Since the last glacial maximum, the bulk carbon and sulfur isotopic data suggest that the SMTZ was relatively stable at roughly the same depth with a continuous but decreased flux of methane. Foraminiferal abundances can increase due to a sudden input of high-quality organic matter, or enhanced reproductive activity and/or rapid growth, which provided possible conditions for the main biogeochemical process of AOM in sediments. The enrichment of $U$ and Mo in foraminifera-rich interval may be related to turbidite deposition, which slowed oxygen diffusion into the sediment, allowing anoxic environments to occur in the sediments. These observations suggest that the $U$ has possibly experienced remobilization as a consequence of downward penetration of the oxidation front from the oxygen-rich bottom currents. This pattern indicates that physical reworking (turbidity currents and bottom currents) of the seabed [3,79], which is common on continental margins, can significantly influence the behavior of $\mathrm{U}$ and other redox-sensitive and/or sulfide-associated metals. In the second stage ( 19.0 ka), seeping of methane-rich fluids was also observed in Unit III, where most of the seeping methane was consumed by AOM-SR. Due to the high content of CRS and the enrichment of ${ }^{34} \mathrm{~S}$, the flow of methane fluids was stable. In summary, the characteristics of methane seepages can be determined according to the composition and isotope characteristics of authigenic minerals in marine sediments. The analysis of sediment geochemistry should consider turbidites and other non-steady state factors.

\section{Conclusions}

Detailed data of authigenic minerals, inorganic elements and stable isotopes were reported for cold-seep sediments at the site 973-4 in the northern slope of the South China Sea, along with the associated grain size and $\mathrm{AMS}^{14} \mathrm{C}$ dating of planktonic foraminifera. This suggests that an abrupt increase in methane flux occurred between $14 \mathrm{ka}$ and $19 \mathrm{ka}$, bringing sediments with an 
older age of 34.09-39.65 ka. The sampling interval of Unit II might have been affected by turbidity current. Therefore, the formation of the foraminifera-rich turbidites reported here might be closely related to the gas hydrate dissociation and increased carbonate productivity during the last glacial maximum, which provides a broad context for the settings and specific controls that facilitate AOM. The foraminifera-rich interval (Unit II) of cold seep sediments was probably linked to the phenomenon of inconsecutive sedimentary sequence due to the turbidites, which resulted in the lack of $\mathrm{Fe}, \mathrm{Mn}$, and $\mathrm{Ba}$ enrichment. The ${ }^{34} \mathrm{~S}_{\mathrm{CRS}}$ enrichments and abundant CRS contents in the authigenic sulfides in SMTZ within Unit III (619-900 cmbsf) reflected the constant methane fluxes supported by constant fluid flow rate. The dynamics of fluid flows at seep were characterized by changes in flow intensity and episodic seepages, which might control the species, composition and formation depth of authigenic minerals.

Author Contributions: Methodology, T.S. and R.X.; data curation, M.P.; writing—original draft preparation, T.S.; writing-review and editing, D.W.; supervision, X.C. and L.L.; project administration, Y.Y.; funding acquisition, D.W. and N.W.

Funding: This research was partially supported by Institution of South China Sea Ecology and Environmental Engineering, Chinese Academy of Sciences (no. ISEE2018YB03), the Special project for marine economy development of Guangdong Province (no. GDME-2018D002), Evaluation and Detection Technology Laboratory of marine mineral resources, the Municipal Science and Technology Program of Guangzhou (no. 201904010311) and Qingdao National Laboratory for Marine Science and Technology (no. KC201703).

Acknowledgments: The samples were collected by the "Haiyang-6" Scientific Research Boat of the Guangzhou Marine Geological Survey, China. The authors thank the voyage scientists for their hard work in collecting the research samples. The authors also thank the Guangzhou Institute of Geochemistry CAS for total organic carbon analysis, Wuhan Institute of Science and Technology Co. Ltd. for trace elements analysis, and the Analysis and Testing Center of China University of Geosciences (Wuhan, China) for S isotope tests. This research was partially supported by Institution of South China Sea Ecology and Environmental Engineering, Chinese Academy of Sciences (no. ISEE2018YB03), the Special project for marine economy development of Guangdong Province (no. GDME-2018D002), Evaluation and Detection Technology Laboratory of marine mineral resources, the Municipal Science and Technology Program of Guangzhou (no. 201904010311) and Qingdao National Laboratory for Marine Science and Technology (no. KC201703).

Conflicts of Interest: The authors declare no conflict of interest.

Appendix A Supporting Information

Table A1. CRS contents and the values of $\delta^{34} \mathrm{~S}$ in sediment site $973-4$.

\begin{tabular}{|c|c|c|c|c|c|c|c|c|c|c|c|}
\hline $\begin{array}{l}\text { Depth } \\
\text { (cm) }\end{array}$ & $\begin{array}{c}\text { CRS } \\
\text { (wt. \%) }\end{array}$ & $\begin{array}{c}\delta^{34} \\
\text { S\%oVCDT }\end{array}$ & $\begin{array}{c}\text { Extraction } \\
\text { Rate }\end{array}$ & $\begin{array}{l}\text { Depth } \\
(\mathrm{cm})\end{array}$ & $\begin{array}{c}\text { CRS } \\
\text { (wt. \%) }\end{array}$ & $\begin{array}{c}\delta^{34} S \\
\% \text { o VCDT }\end{array}$ & $\begin{array}{c}\text { Extraction } \\
\text { Rate }\end{array}$ & $\begin{array}{c}\text { Depth } \\
(\mathrm{cm})\end{array}$ & $\begin{array}{c}\text { CRS } \\
\text { (wt.\%) }\end{array}$ & $\begin{array}{c}\delta^{34} S \\
\% \text { oVCDT }\end{array}$ & $\begin{array}{c}\text { Extraction } \\
\text { Rate }\end{array}$ \\
\hline 63 & - & -14.68 & \multirow{4}{*}{$88.89 \%$} & 483 & 0.350 & -42.74 & \multirow{4}{*}{$89.92 \%$} & 783 & 0.181 & 4.02 & \multirow{4}{*}{$88.03 \%$} \\
\hline 143 & - & -20.16 & & 523 & 0.123 & -43.00 & & 823 & 0.129 & 8.25 & \\
\hline 183 & - & -27.03 & & 543 & 0.264 & - & & 843 & 1.080 & 17.42 & \\
\hline 263 & 0.140 & -31.58 & & 563 & 0.315 & - & & 863 & 1.110 & 22.05 & \\
\hline 323 & 0.072 & -36.34 & \multirow[t]{3}{*}{$92.08 \%$} & 623 & 1.385 & - & \multirow[t]{3}{*}{$88.13 \%$} & 963 & 0.163 & 8.38 & \multirow[t]{3}{*}{$89.11 \%$} \\
\hline 343 & 0.103 & -40.26 & & 643 & 0.406 & 2.55 & & 1003 & 0.130 & 8.07 & \\
\hline 363 & 0.139 & -42.18 & & 663 & 1.114 & -3.89 & & 1103 & 0.183 & 5.94 & \\
\hline 383 & 0.114 & -41.90 & \multirow[b]{3}{*}{$91.40 \%$} & 683 & 1.211 & 20.13 & \multirow[b]{3}{*}{$91.89 \%$} & 1163 & 0.101 & 10.41 & \multirow[b]{3}{*}{$88.75 \%$} \\
\hline 403 & 0.133 & -41.08 & & 703 & 0.254 & -5.89 & & 1203 & 0.293 & 6.01 & \\
\hline 423 & 0.170 & -42.16 & & 723 & 0.874 & - & & 1223 & 0.023 & 3.10 & \\
\hline
\end{tabular}


Table A2. Redox-sensitive element contents in the sediments of site 973-4.

\begin{tabular}{|c|c|c|c|c|c|c|c|c|c|c|c|}
\hline $\begin{array}{l}\text { Depth } \\
\text { (cm) }\end{array}$ & $\begin{array}{l}\text { Mo } \\
\text { ppm }\end{array}$ & $\underset{\mathrm{ppm}}{\mathrm{U}}$ & $\begin{array}{c}\mathrm{V} \\
\text { ppm }\end{array}$ & $\begin{array}{c}\mathrm{Fe} \\
(\%)\end{array}$ & $\begin{array}{l}\text { Mn } \\
(\%)\end{array}$ & $\begin{array}{l}\text { Depth } \\
\text { (cm) }\end{array}$ & $\begin{array}{c}\text { Mo } \\
\text { ppm }\end{array}$ & $\underset{\mathrm{ppm}}{\mathrm{U}}$ & $\begin{array}{c}\mathrm{V} \\
\mathrm{ppm}\end{array}$ & $\begin{array}{c}\mathrm{Fe} \\
(\%)\end{array}$ & $\begin{array}{l}\text { Mn } \\
(\%)\end{array}$ \\
\hline 20 & 0.52 & 118.23 & 40.39 & 3.67 & 0.051 & 679 & 0.73 & 118.30 & 44.54 & 3.75 & 0.055 \\
\hline 40 & 0.30 & 124.71 & 41.00 & 3.66 & 0.047 & 699 & 0.50 & 116.66 & 45.24 & 3.71 & 0.055 \\
\hline 59 & 0.33 & 114.99 & 40.67 & 3.77 & 0.045 & 719 & 0.48 & 117.65 & 45.49 & 3.62 & 0.057 \\
\hline 79 & 0.27 & 110.45 & 39.24 & 3.73 & 0.048 & 739 & 0.52 & 115.90 & 44.96 & 3.80 & 0.051 \\
\hline 99 & 0.26 & 114.94 & 40.73 & 3.67 & 0.049 & 759 & 0.52 & 112.76 & 44.25 & 3.71 & 0.052 \\
\hline 119 & 0.25 & 112.64 & 41.44 & 3.66 & 0.046 & 779 & 0.54 & 120.46 & 46.31 & 3.72 & 0.054 \\
\hline 139 & 0.24 & 110.87 & 40.09 & 3.65 & 0.046 & 799 & 0.48 & 117.85 & 45.46 & 3.61 & 0.060 \\
\hline 159 & 0.24 & 107.69 & 39.77 & 3.58 & 0.045 & 819 & 0.56 & 118.53 & 46.69 & 3.63 & 0.066 \\
\hline 179 & 0.27 & 107.32 & 39.22 & 3.56 & 0.044 & 839 & 0.54 & 120.35 & 46.63 & 3.72 & 0.064 \\
\hline 199 & 0.31 & 114.03 & 41.72 & 3.62 & 0.044 & 859 & 0.47 & 119.52 & 44.18 & 3.66 & 0.068 \\
\hline 219 & 0.62 & 110.50 & 39.88 & 4.09 & 0.042 & 879 & 0.42 & 120.28 & 46.11 & 3.74 & 0.064 \\
\hline 239 & 0.26 & 111.42 & 41.08 & 3.62 & 0.043 & 899 & 0.62 & 131.48 & 46.32 & 4.28 & 0.067 \\
\hline 259 & 0.27 & 113.28 & 43.10 & 3.68 & 0.052 & 919 & 0.49 & 132.06 & 45.47 & 3.77 & 0.062 \\
\hline 279 & 0.31 & 111.56 & 41.22 & 3.74 & 0.050 & 939 & 0.60 & 134.03 & 46.26 & 3.95 & 0.066 \\
\hline 299 & 0.28 & 114.31 & 44.56 & 3.79 & 0.047 & 959 & 0.54 & 129.89 & 45.67 & 4.02 & 0.071 \\
\hline 319 & 0.28 & 113.74 & 43.25 & 3.78 & 0.049 & 979 & 0.60 & 132.57 & 45.43 & 3.99 & 0.072 \\
\hline 339 & 0.32 & 115.56 & 43.92 & 3.80 & 0.046 & 999 & 0.65 & 131.06 & 44.86 & 4.02 & 0.071 \\
\hline 359 & 0.34 & 122.71 & 46.28 & 3.87 & 0.046 & 1019 & 0.44 & 129.81 & 45.49 & 3.91 & 0.081 \\
\hline 379 & 0.49 & 123.80 & 45.87 & 3.87 & 0.049 & 1059 & 0.80 & 125.71 & 43.82 & 4.01 & 0.087 \\
\hline 399 & 0.35 & 129.75 & 47.58 & 3.86 & 0.047 & 1079 & 0.59 & 119.12 & 43.71 & 3.93 & 0.081 \\
\hline 419 & 0.43 & 128.41 & 47.13 & 3.97 & 0.046 & 1099 & 0.48 & 120.02 & 44.07 & 4.05 & 0.074 \\
\hline 439 & 0.33 & 119.39 & 47.19 & 3.89 & 0.046 & 1119 & 0.68 & 121.50 & 44.35 & 4.12 & 0.081 \\
\hline 459 & 0.29 & 73.02 & 26.38 & 3.03 & 0.035 & 1139 & 0.51 & 124.06 & 43.41 & 4.12 & 0.084 \\
\hline 479 & 0.94 & 96.97 & 39.15 & 3.26 & 0.037 & 1180 & 0.54 & 126.77 & 44.25 & 3.92 & 0.076 \\
\hline 499 & 0.40 & 104.41 & 36.80 & 3.33 & 0.035 & 1200 & 0.49 & 128.89 & 44.27 & 3.95 & 0.086 \\
\hline 519 & 0.27 & 95.96 & 33.04 & 3.22 & 0.032 & 1220 & 0.56 & 127.57 & 45.12 & 3.90 & 0.075 \\
\hline 539 & 0.48 & 97.87 & 34.90 & 3.29 & 0.035 & 1260 & 0.62 & 131.88 & 45.95 & 4.14 & 0.090 \\
\hline 559 & 0.36 & 86.34 & 31.46 & 3.18 & 0.031 & 1280 & 0.61 & 114.87 & 42.85 & 4.03 & 0.081 \\
\hline 579 & 0.40 & 94.41 & 32.39 & 3.22 & 0.034 & 1300 & 0.66 & 127.67 & 44.81 & 3.97 & 0.087 \\
\hline 599 & 0.27 & 101.67 & 34.97 & 3.33 & 0.036 & 1320 & 0.72 & 131.27 & 45.06 & 4.05 & 0.080 \\
\hline 619 & 0.69 & 110.83 & 41.84 & 3.52 & 0.042 & 1340 & 0.57 & 127.80 & 45.24 & 3.94 & 0.077 \\
\hline 639 & 0.86 & 115.18 & 43.81 & 3.74 & 0.051 & 1360 & 0.63 & 126.95 & 45.51 & 3.75 & 0.055 \\
\hline 659 & 1.12 & 116.55 & 45.43 & 3.82 & 0.058 & & & & & & \\
\hline
\end{tabular}

\section{References}

1. Bohrmann, G.; Torres, M.E. Gas Hydrates in Marine Sediments; Springer: Berlin/Heidelberg, Germany, 2006.

2. Dickens, G.R.; Rea, D.K.; Owen, R.M. Dissociation of oceanic methane hydrate as a cause of the carbon isotope excursion at the end of the. Paleoceanography 1995, 10, 965-971. [CrossRef]

3. Kasten, S.; Zabel, M.; Heuer, V.; Hensen, C. Processes and Signals of Nonsteady-State Diagenesis in Deep-Sea Sediments and their Pore Waters. In The South Atlantic in the Late Quaternary: Reconstruction of Material Budgets and Current Systems; Springer: Berlin/Heidelberg, Germany, 2003.

4. Zimov, S.A.; Zimov, N. Late Quaternary Atmospheric CH4 Isotope Record Suggests Permafrost was a Source of CH4 and CO2; American Geophysical Union Fall Meeting: San Francisco, CA, USA, 2009.

5. Wellsbury, P.; Mather, I.; Parkes, R.J. Geomicrobiology of deep, low organic carbon sediments in the Woodlark Basin, Pacific Ocean. FEMS Microbiol. Ecol. 2002, 42, 59-70. [CrossRef] [PubMed]

6. Li, N.; Feng, D.; Chen, L.; Wang, H.; Chen, D. Using sediment geochemistry to infer temporal variation of methane flux at a cold seep in the South China Sea. Mar. Pet. Geol. 2016, 77, 835-845. [CrossRef]

7. Bo, T. Bacterial Manganese and Iron Reduction in Aquatic Sediments. Adv. Microb. Ecol. 2000, 16, 41-84.

8. Wegener, G.; Krukenberg, V.; Riedel, D.; Tegetmeyer, H.E.; Boetius, A. Intercellular wiring enables electron transfer between methanotrophic archaea and bacteria. Nature 2015, 526, 587-590. [CrossRef] [PubMed]

9. Haqqmisra, J.D.; Domagalgoldman, S.D.; Kasting, P.J.; Kasting, J.F. A revised, hazy methane greenhouse for the Archean Earth. Astrobiology 2008, 8, 1127-1137. [CrossRef] [PubMed] 
10. Suess, E. Marine cold seeps and their manifestations: Geological control, biogeochemical criteria and environmental conditions. Int. J. Earth Sci. 2014, 103, 1889-1916. [CrossRef]

11. Bayon, G.; Dupré, S.; Ponzevera, E.; Etoubleau, J.; Chéron, S.; Pierre, C.; Mascle, J.; Boetius, A.; Lange, G.J.D. Formation of carbonate chimneys in the Mediterranean Sea linked to deep-water oxygen depletion. Nat. Geosci. 2013, 6, 755-760. [CrossRef]

12. Boetius, A.; Ravenschlag, K.; Schubert, C.J.; Rickert, D.; Widdel, F.; Gieseke, A.; Amann, R.; Örgensen, B.B.; Witte, U.; Pfannkuche, O. A marine microbial consortium apparently mediating anaerobic oxidation of methane. Nature 2000, 407, 623. [CrossRef]

13. Schwartz, W. R. A. Berner, Early Diagenesis, A Theoretical Approach. XII + 241 S., 17 Tab., 60 Abb. Princeton, N.Y. 1980. Princeton University Press. \$ 31.50 (Cloth), \$ 13.00 (Paperb.). J. Basic Microbiol. 1981, $21,765$.

14. Haese, R.R.; Meile, C.; Van Cappellen, P.; De Lange, G.J. Carbon geochemistry of cold seeps: Methane fluxes and transformation in sediments from Kazan mud volcano, eastern Mediterranean Sea. Earth Planet. Sci. Lett. 2003, 212, 361-375. [CrossRef]

15. Yoshinaga, M.Y.; Holler, T.; Goldhammer, T.; Wegener, G.; Pohlman, J.W.; Brunner, B.; Kuypers, M.M.M.; Hinrichs, K.U.; Elvert, M. Carbon isotope equilibration during sulphate-limited anaerobic oxidation of methane. Nat. GeoSci. 2014, 7, 190-194. [CrossRef]

16. Jørgensen, P.R.; Urup, J.; Helstrup, T.; Jensen, M.B.; Eiland, F.; Vinther, F.P. Transport and reduction of nitrate in clayey till underneath forest and arable land. J. Contam. Hydrol. 2004, 73, 207-226. [CrossRef] [PubMed]

17. Reeburgh, W.S. Oceanic Methane Biogeochemistry. Chem. Rev. 2007, 107, 486-513. [CrossRef] [PubMed]

18. Taylor, K.G.; Macquaker, J.H.S. Iron in marine sediments: Minerals as records of chemical environments. J. Reprod. Fertil. Suppl. 2011, 7, 113-118. [CrossRef]

19. David Rickard, A.; Luther, G.W. Chemistry of Iron Sulfides. Chem. Rev. 2007, 107, 514-562. [CrossRef] [PubMed]

20. Borowski, W.S.; Rodriguez, N.M.; Paull, C.K.; Iii, W.U. Are 34 S-enriched authigenic sulfide minerals a proxy for elevated methane flux and gas hydrates in the geologic record? Mar. Pet. Geol. 2013, 43, 381-395. [CrossRef]

21. Hanson, R.S.; Hanson, T.E. Methanotrophic bacteria. Microbiol. Rev. 1996, 60, 439-471. [PubMed]

22. Peketi, A.; Joshi, R.K.; Patil, D.J.; Srinivas, P.L.; Dayal, A.M. Tracing the Paleo sulfate-methane transition zones and H2S seepage events in marine sediments: An application of C-S-Mo systematics. Geochem. Geophys. Geosyst. 2012, 13. [CrossRef]

23. Lim, Y.C.; Lin, S.; Yang, T.F.; Chen, Y.G.; Liu, C.S. Variations of methane induced pyrite formation in the accretionary wedge sediments offshore Southwestern Taiwan. Mar. Pet. Geol. 2011, 28, 1829-1837. [CrossRef]

24. Chen, F.; Hu, Y.; Feng, D.; Zhang, X.; Cheng, S.; Cao, J.; Lu, H.; Chen, D. Evidence of intense methane seepages from molybdenum enrichments in gas hydrate-bearing sediments of the northern South China Sea. Chem Geol. 2016, 443, 173-181. [CrossRef]

25. Tribovillard, N.; Bout-Roumazeilles, V.; Algeo, T.; Lyons, T.; Sionneau, T.; Montero-Serrano, J.; Riboulleau, A.; Baudin, F. Paleodepositional conditions in the Orca Basin as inferred from organic matter and trace metal contents. Mar. Geol. 2008, 254, 62-72. [CrossRef]

26. Argentino, C.; Lugli, F.; Cipriani, A.; Conti, S.; Fontana, D. A deep fluid source of radiogenic Sr and highly dynamic seepage conditions recorded in Miocene seep carbonates of the northern Apennines (Italy). Chem. Geol. 2019, 522, 135-147. [CrossRef]

27. Mutti, D.O.; Mitchell, G.L.; Jones, L.A.; Friedman, N.E.; Frane, S.L.; Lin, W.K.; Moeschberger, M.L.; Zadnik, K. Accommodation, Acuity, and their Relationship to Emmetropization in Infants. Optom. Vis. Sci. 2009, 86, 666-676. [CrossRef]

28. Piper, D.J.W.; Normark, W.R. Processes That Initiate Turbidity Currents and Their Influence on Turbidites: A Marine Geology Perspective. J. Sediment. Res. 2009, 79, 347-362. [CrossRef]

29. Feng, D.; Roberts, H.H.; Cheng, H.; Peckmann, J.; Bohrmann, G.; Edwards, R.L.; Chen, D. U/Th dating of cold-seep carbonates: An initial comparison. Deep. Sea Res. Part II Top. Stud. Oceanogr. 2010, 57, 2055-2060. [CrossRef]

30. Bayon, G.; Henderson, G.M.; Etoubleau, J.; Caprais, J.C.; Ruffine, L.; Marsset, T.; Dennielou, B.; Cauquil, E.; Voisset, M.; Sultan, N. U-Th isotope constraints on gas hydrate and pockmark dynamics at the Niger delta margin. Mar. Geol. 2015, 370, 87-98. [CrossRef] 
31. Liu, B.L.; Wang, Y.P.; Wang, J.Z.; Jian, P.; Wang, Y.H.; Cheng, D.W.; Ye, L.I. Geochemical Characters of Ree in the Seafloor Sediment in Northern Continental Slope of the South China Sea and Analysis of Source of Material and Diagenesis Environment. Mar. Geol. Quat. Geol. 2004, 24, 17-23.

32. Luan, L.; Lippman, T.M.; Hicks, C.W.; Bert, J.A.; Auslaender, O.M.; Chu, J.H.; Analytis, J.G.; Fisher, I.R.; Moler, K.A. Local measurement of the superfluid density in the pnictide superconductor $\mathrm{Ba}(\mathrm{Fe}(1-\mathrm{x}) \mathrm{Co}(\mathrm{x}))(2) \mathrm{As}(2)$ across the superconducting dome. Phys. Rev. Lett. 2011, 106, 067001. [CrossRef]

33. Zhang, G.; Zhu, Y.; Xu, H. Gas Hydrate on the Passive Continental Margin and Its Pool-formation Process. Geol. Rev. 2003, 2, 181-186.

34. Sha, Z.B.; Wang, H.B.; Yang, M.Z.; Liang, J.Q.; Zhang, G.X.; Liu, X.W.; Gong, Y.H. Study on Recognizing Technology of Gas Hydrates Zone. GeoScience 2008, 22, 438-446.

35. Wu, N.; Yang, S.X.; Wang, H.B.; Liang, J.Q.; Gong, Y.H.; Lu, Z.Q.; Wu, D.; Guan, H.X. Gas-bearing fluid influx sub-system for gas hydrate geological system in Shenhu Area, Northern South China Sea. Chin. J. Geophys. 2009, 6, 1641-1650.

36. Zhang, A.; Al, E. Effect of Acid Stress on Growth of and Ca and Mg Uptake by Maize of Different Genotypes. Chin. J. Appl. Environ. Biol. 2007, 6, 794-798.

37. Zhang, G.; Liang, J.; Lu, J.; Yang, S.; Zhang, M.; Su, X.; Xu, H.; Fu, S.; Kuang, Z. Characteristics of natural gas hydrate reservoirs on the northeastern slope of the South China Sea. Nat. Gas Ind. 2014, 11, 1-10.

38. Zhong, C.; Yan, W.; Chen, M.; Muhong, C. Discovery of seep authigenic carbonate nodules on northern continental slope of South China Sea: New evidence of gas hydrate. J. Trop. Oceanogr. 2006, 51, 1065-1072.

39. Daidai, W.U.; Nengyou, W.U.; Shaoying, F.U.; Liang, J.; Guan, H. Geochemical Characteristics of Shallow Sediments in the Gas Hydrate Distribution Area of Dongsha, the Northern South China Sea. Mar. Geol. Quat. Geol. 2010, 30, 41-51.

40. Lu, H.; Liu, J.; Chen, F.; Liao, Z.L.; Sun, X.M.; Xin, S.U. Mineralogy and stable isotopic composition of authigenic carbonates in bottom sediments in the offshore area of southwest Taiwan, South China Sea: Evidence for gas hydrates occurrence. Earth Sci. Front. 2005, 17, 981-1007.

41. He, F.; Chen, Y.C.; Liu, A.B. The Characteristics of Geochemical and Hydrocarbon-Generation Potential Evaluation in Hydrocarbon Source Rock of Shanxi Group of Sulige Area. Comput. Tech. Geophys. GeoChem. Explor. 2009, 618-633. [CrossRef]

42. Pan, M.; Wu, D.; Yang, F.; Sun, T.; Wu, N.; Liu, L. Geochemical sedimentary evidence from core 973-2 for methane activity near the Jiulong Methane Reef in the northern South China Sea. Interpretation 2017, 6, 1-39. [CrossRef]

43. Canfield, P.; Forbes, L. Supression of drain conductance transients, drain current oscillations, and low-frequency generation-Recombination noise in GaAs FET's using buried channels. IEEE Trans. Electron Devices 1986, 33, 925-928. [CrossRef]

44. Wu, Y.; Shi, X.; Zou, J.; Cheng, Z.; Wang, K.; Ge, S.; Shi, F. Benthic foraminiferal $\delta 13 \mathrm{C}$ minimum events in the southeastern Okhotsk Sea over the last $180 \mathrm{ka}$. Chin. Sci. Bull. 2014, 59, 3066-3074. [CrossRef]

45. Gibbs, A.K. The Continental Crust: Its Composition and Evolution. J. Geol. 1985, 4, 632-633.

46. Ying, Q. Response of Cold Seep Benthic Foraminifera and Methane Eruption in Northern Slope of the South China Sea. Master's Thesis, China University of GeoSciences, Wuhan, Beijing, 2013.

47. Lin, Q.; Wang, J.; Fu, S.; Lu, H.; Bu, Q.; Lin, R.; Sun, F. Elemental sulfur in northern South China Sea sediments and its significance. Sci. China Earth Sci. 2015, 58, 2271-2278. [CrossRef]

48. Zhang, B.; Pan, M.; Wu, D.; Wu, N. Distribution and isotopic composition of foraminifera at cold-seep Site 973-4 in the Dongsha area, northeastern South China Sea. J. Asian Earth Sci. 2018, 168, 145-154. [CrossRef]

49. Liu, J.; Izon, G.; Wang, J.; Antler, G.; Wang, Z.; Zhao, J.; Egger, M. Vivianite formation in methane-rich deep-sea sediments from the South China Sea. Biogeoscience 2018, 15, 6329-6348. [CrossRef]

50. Thiel, V.; Peckmann, J.; Richnow, H.H.; Luth, U.; Reitner, J.; Michaelis, W. Molecular signals for anaerobic methane oxidation in Black Sea seep carbonates and a microbial mat. Mar. Chem. 2001, 73, 97-112. [CrossRef]

51. Peckmann, J.; Thiel, V.; Reitner, J.; Taviani, M.; Aharon, P.; Michaelis, W. A Microbial Mat of a Large Sulfur Bacterium Preserved in a Miocene Methane-Seep Limestone. GeoMicrobiol. J. 2004, 21, 247-255. [CrossRef]

52. Formolo, M.J.; Lyons, T.W. Sulfur biogeochemistry of cold seeps in the Green Canyon region of the Gulf of Mexico. Geochim. Cosmochim. Acta 2013, 119, 264-285. [CrossRef]

53. Berner, R.A.; Scott, M.R.; Thomlinson, C. Carbonate Alkalinity in the Pore Waters of Anoxic Marine Sediments. Limnol. Oceanogr. 1970, 15, 544-549. [CrossRef] 
54. Morse, J.W.; Berner, R.A. What determines sedimentary C S ratios? Geochim. Cosmochim. Acta 1995, 59, 1073-1077. [CrossRef]

55. Habicht, K.; Canfield, D.E. The Effect of Sulfate Concentration on the Sulfur Isotope Fractionation During Sulfate Reduction by Sulfate-reducing Bacteria. In Proceedings of the Eleventh Annual VM Goldschmidt Conference, Hot Springs, VA, USA, 20-24 May 2001.

56. Jørgensen, B.B.; Findlay, A.J.; Pellerin, A. The Biogeochemical Sulfur Cycle of Marine Sediments. Front. Microbiol. 2019, 10, 1-27. [CrossRef]

57. Sugita, A.; Sugii, A.; Sato, K.; Zhang, X.Y.; Dai, A.L.; Taguchi, G.; Shimosaka, M. Cloning and Characterization of a Gene Coding for a Major Extracellular Chitosanase from the Koji Mold Aspergillus oryzae. BioSci. Biotechnol. Biochem. 2012, 76, 193-195. [CrossRef]

58. Aharon, P.; Schwarcz, H.P.; Roberts, H.H. Radiometric dating of submarine hydrocarbon seeps in the Gulf of Mexico. Geol. Soc. Am. Bull. 1997, 109, 568-579. [CrossRef]

59. Watanabe, Y.; Nakai, S.I.; Hiruta, A.; Matsumoto, R.; Yoshida, K. U-Th dating of carbonate nodules from methane seeps off Joetsu, Eastern Margin of Japan Sea. Earth Planet. Sci. Lett. 2008, 272, 89-96. [CrossRef]

60. Pan, M. Evidence from Foraminifera and Geochemical Characteristics of Sediments for Methane Seeps in the Northern Slope of the South China Sea; Chinese Academy of Sciences: Beijing, China, 2017; pp. 31-32.

61. Labeyrie, L.D.; Duplessy, J.C.; Blanc, P.L. Variations in mode of formation and temperature of oceanic deep waters over the past 125,000 years. Nature 1987, 327, 477-482. [CrossRef]

62. Peckmann, J.; Reimer, A.; Luth, U.; Luth, C.; Hansen, B.T.; Heinicke, C.; Hoefs, J.; Reitner, J. Methane-derived carbonates and authigenic pyrite from the northwestern Black Sea. Mar. Geol. 2001, 177, 129-150. [CrossRef]

63. Wang, Z.; Yang, S.; Zhang, Z.; Lan, X.; Gu, Z.; Zhang, X. Paleo-fluvial sedimentation on the outer shelf of the East China Sea during the last glacial maximum. Chin. J. Oceanol. Limnol. 2013, 31, 886-894. [CrossRef]

64. Liu, J.P.; Xu, K.H.; Li, A.C.; Milliman, J.D.; Velozzi, D.M.; Xiao, S.B.; Yang, Z.S. Flux and fate of Yangtze River sediment delivered to the East China Sea. Geomorphology 2007, 85, 208-224. [CrossRef]

65. Dou, Y.; Yang, S.; Liu, Z.; Clift, P.D.; Shi, X.; Hua, Y.; Berne, S. Provenance discrimination of siliciclastic sediments in the middle Okinawa Trough since $30 \mathrm{ka}$ : Constraints from rare earth element compositions. Mar. Geol. 2010, 275, 212-220. [CrossRef]

66. Zhao, Y.; Liu, Z.; Colin, C.; Xie, X.; Wu, Q. Turbidite deposition in the southern South China Sea during the last glacial: Evidence from grain-size and major elements records. Chin. Sci. Bull. 2011, 56, 3558-3565. [CrossRef]

67. Gulin, S.B.; Polikarpov, G.G.; Egorov, V.N. The age of microbial carbonate structures grown at methane seeps in the Black Sea with an implication of dating of the seeping methane. Mar. Chem. 2003, 84, 67-72. [CrossRef]

68. Tong, H.; Feng, D.; Cheng, H.; Yang, S.; Wang, H.; Min, A.G.; Edwards, R.L.; Chen, Z. Authigenic carbonates from seeps on the northern continental slope of the South China Sea: New insights into fluid sources and geochronology. Mar. Pet. Geol. 2013, 43, 260-271. [CrossRef]

69. Han, X.; Suess, E.; Liebetrau, V.; Eisenhauer, A.; Huang, Y. Past methane release events and environmental conditions at the upper continental slope of the South China Sea: Constraints by seep carbonates. Int. J. Earth Sci. 2014, 103, 1873-1887. [CrossRef]

70. Jian, Z.; Wang, L.; Kienast, M.; Sarnthein, M.; Kuhnt, W. Benthic foraminiferal paleoceanography of the South China Sea over the last 40,000 years. Mar. Geol. 1999, 156, 159-186. [CrossRef]

71. Abu-Zied, B.M.; Schwieger, W.; Unger, A. Nitrous oxide decomposition over transition metal exchanged ZSM-5 zeolites prepared by the solid-state ion-exchange method. Appl. Catal. B Environ. 2008, 84, 277-288. [CrossRef]

72. Fang, C. Characteristics of Turbidity Current Deposits of Core SA14-34 in Deep Sea Basin of the Western South China Sea. Geol. Res. South China Sea 2007, 1, 31-39.

73. Scholz, A.; Lang, V.; Henschler, R.; Czabanka, M.; Vajkoczy, P.; Chavakis, E.; Drynski, J.; Harter, P.N.; Mittelbronn, M.; Dumont, D.J. Angiopoietin-2 promotes myeloid cell infiltration in a $\beta 2$-integrin-dependent manner. Blood 2011, 118, 5050-5059. [CrossRef]

74. Tribovillard, N.; Algeo, T.J.; Lyons, T.; Riboulleau, A. Trace metals as paleoredox and paleoproductivity proxies: An update. Chem. Geol. 2006, 232, 12-32. [CrossRef]

75. Anschutz, P.; Jorissen, F.J.; Chaillou, G.; Abu-Zied, R.; Fontanier, C. Recent turbidite deposition in the eastern Atlantic: Early diagenesis and biotic recovery. J. Mar. Res. 2002, 60, 835-854. [CrossRef] 
76. Sato, H.; Hayashi, K.I.; Ogawa, Y.; Kawamura, K. Geochemistry of deep sea sediments at cold seep sites in the Nankai Trough: Insights into the effect of anaerobic oxidation of methane. Mar. Geol. 2012, 323, 47-55. [CrossRef]

77. Hu, Y.; Feng, D.; Peckmann, J.; Roberts, H.; Chen, D. New insights into cerium anomalies and mechanisms of trace metal enrichment in authigenic carbonate from hydrocarbon seeps. Chem. Geol. 2014, 381, 55-66. [CrossRef]

78. Hu, Y.; Chen, L.; Feng, D.; Liang, Q.; Xia, Z.; Chen, D. Geochemical record of methane seepage in authigenic carbonates and surrounding host sediments: A case study from the South China Sea. J. Asian Earth Sci. 2017, 138, 51-61. [CrossRef]

79. Hong, W.-L.; Solomon, E.A.; Torres, M.E. A kinetic-model approach to quantify the effect of mass transport deposits on pore water profiles in the Krishna-Godavari Basin, Bay of Bengal. Mar. Pet. Geol. 2014, 58, 223-232. [CrossRef]

(C) 2019 by the authors. Licensee MDPI, Basel, Switzerland. This article is an open access article distributed under the terms and conditions of the Creative Commons Attribution (CC BY) license (http://creativecommons.org/licenses/by/4.0/). 